Animals at the End of the World 


\author{
LATIN AMERICAN \\ LITERATURE IN \\ TRANSLATION SERIES
}

OTHER BOOKS IN THE SERIES

The Enlightened Army by David Toscana

Human Matter: A Fiction by Rodrigo Rey Rosa

The Last Days of El Comandante by Alberto Barrera Tyszka 


\section{Animals at the End of the World}

Gloria Susana Esquivel

Translated by Robin Myers

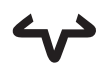

UNIVERSITY OF TEXAS PRESS Austin 
Animales del fin del mundo copyright (C) 2017 by Gloria Susana Esquivel c/o Indent Literary Agency

www.indentagency.com

Translation copyright (C) 2020 by Robin Myers

All rights reserved

Printed in the United States of America

Project editor: Lynne Chapman

Cover design: Isaac Tobin

Interior typesetting: Cassandra Cisneros

Typeset in Spectral

Book cover printed by Phoenix Color, interior printed by Sheridan Books

Requests for permission to reproduce material from this work should be sent to:

Permissions

University of Texas Press

P.O. Box 7819

Austin, TX 78713-7819

utpress.utexas.edu/rp-form

@ The paper used in this book meets the minimum requirements of ANSI/NISO Z39.48-1992 (R1997) (Permanence of Paper).

Library of Congress Cataloging-in-Publication Data

Names: Esquivel, Gloria Susana, author. | Myers, Robin, 1987-, translator.

Title: Animals at the end of the world / Gloria Susana Esquivel ; translated by Robin Myers.

Other titles: Animales del fin del mundo. English

Description: Austin : University of Texas Press, 2020.| Series: Latin American literature in translation series

Identifiers: LCCN 2019034300

ISBN 978-1-4773-2016-7 (paperback)

ISBN 978-1-4773-2124-9 (library ebook)

ISBN 978-1-4773-2125-6 (non-library ebook)

Subjects: LCSH: Girls—Fiction. | Imagination-Fiction. | Fear-Fiction. | Colombian fiction-21st century.

Classification: LCC PQ8180.415.S69 A7213 2020 | DDC 863/.7—dc23

LC record available at https://lccn.loc.gov/2019034300

doi:10.7560/320167 
And one shall say unto him, What are these wounds in thine hands?

Then he shall answer, Those with which I was wounded in the house of them that loved me.

ZECHARIAH 13:6

Like a small bird sealed off from daylight: that was my childhood.

LOUISE GLÜCK 
This page intentionally left blank. 
Animals at the End of the World 
This page intentionally left blank. 
I 
This page intentionally left blank. 